\title{
Impact of Intangible Factors on Business Value
}

\author{
Inna Krasiuk
}

$\mathrm{PhD}$, Deputy head of the branch bank, PJSC CB "PrivatBank", Ukraine

\section{Yelena Demidova}

Lecturer of the Department of Social Work, Belarusian State Pedagogical University named after Maxim Tank; Director of the State Institution "Territorial Center of Public Social Service of Minsk", Minsk, the Republic of Belarus

\begin{abstract}
The global financial and economic crisis of 2008-2009 has caused a significant drop in business efficiency. Today's management model of the overwhelming majority of companies is oriented towards satisfying the interests of owners and business groups, while the interests of clients, creditors, state and society are not sufficiently taken into account. This creates barriers to the growth of business value, which today has become a generally recognized indicator of the success, sustainability and investment attractiveness of companies. It is the reason for the introduction of the policy of value-oriented management of a company aimed at preserving and increasing the value of business, harmonizing the economic interests of all its stakeholders.
\end{abstract}

Keywords: intangible factors, cost, business, management, human capital.

\section{JEL Classification: M21.}

(C) The Authors, 2017. This article is published with open access at ARMG Publishing.

\section{Introduction}

Since the 60s of the last century, the concept of the enterprise value management has been born in the world. It was based on the understanding of the fact that for business owners the central issue was the growth of their welfare, which is measured not by the amount of resources involved in production, but by the value of their business. This management approach is called Value-Based Management. Value-Based Management is a management concept aimed at qualitative improving the strategic and operational decisions at all levels of the organization by concentrating efforts on key value factors (Modigliani et al., 1958).

As shown in T. Copeland's work (Favaro, 2003), the activity of value-oriented companies should be based on value-based thinking, which in its turn is conditioned by the presence of two components: system of value measurement and value ideology. Measuring value requires awareness of the process of creating value and maintaining the balance between long-term and short-term goals. Value ideology is based on the activities of the top management of the company in creation of value, ability to take even unpopular solutions, if they promise to increase value in the long-term prospects.

Theoretical foundations and peculiarities of the practical application of the concept of Value-Based Management of business are considered in works of such foreign scientists as: G. Alexander, R. Brooks, R. Giammarino, A. Damodaran, T. Koller, T. Copeland, A. Marshall, F. Modigliani, S. Penman, P. Rose, J. Sinkey, J. Tobin, Zessin A., L. Edvinsson, J. Favaro, K. Beck, C. Kroeker, A. Millar, N. Rea, A. Davis and others.

In our time, intangible factors make a significant contribution to the investment attractiveness of the company. Among them the key place is given to the human potential and potential of the firm management. As practice shows, investing in human capital gives not only the effect mediated through the growth of material assets of the enterprise, but also directly - in terms of enhancing the image of the company, its prestige and reputation. The basis of the model of evaluation and value management should be a system of management decisions, which allows accurately determine the source of change, as well as the degree of influence of each management decision, its contribution to the creation of a new value. Under the management decision it is understood not only the decision of the manager, but also the decision of business owners in the framework of corporate governance and management of agency relations (Millar, 2013). 
Non-financial factors contributing to the growth of the company's value also include: the quality of management and quality of customer relationship, the company's ability to innovate, the full value of the tasks realization, relationships with creditors and investors. The ability to create and justify the trust of investors, correct information interaction with the market, ability to use profitably the market position is of great significance.

Another factor affecting the company's value is its brand. Brand capital is a set of relationships, conditioned by the value nature of the brand, the main of which are:

$>$ affiliation to long-term assets - non-current assets in general and intangible assets in particular;

$>$ arising as a result the ability to generate cash flows, income, value added and profit;

$>$ the possibility and need for management to increase market value;

$>$ the potential for capitalization of current expenses to increase the company's value within the frame work of the strategy of economic growth, value management, etc. (Zessin, 1982).

\section{Methods and results}

Theoretical and methodological basis of work is the fundamental positions of economic theory, theory of finance, investment and financial management, money and credit, modern concepts of corporate management, as well as scientific works devoted to the problems of formation and management of business value.

The authors used the following methods of scientific research: analysis, synthesis, logical generalization, system and structural analysis.

Investigating the system of Value-Based Management of business, it can be divided into two parts: financial component and non-financial. The use of such an approach to business management should include the following components:

$>$ analysis of the market of the company on which it operates;

$>$ establishment of target benchmarks for the market value of business;

$>$ financial analysis of business, determination of its market value;

$>$ development of a business policy oriented to increasing its value, correction of all business processes in order to increase the market value of the company;

$>$ information awareness of the personnel and its orientation to the growth of market value of the company, formation of the appropriate system of its material incentives.

The analysis of the environment involves the study of a number of factors of macroeconomic impact:

$>$ economic - general economic situation in the country, income level of the population, prospects of interaction of the state with international financial organizations, level of competition and profitability in business;

$>$ political - level of political relations in the country, political regime, development of civil society and freedom of speech, membership in international political blocs;

$>$ legal - legal model of the state, level of intervention of the state on business activity and the existing barriers to entry of new entrants to the market;

$>$ socio-cultural - development of social consciousness, perception of standards of entrepreneurship by society, etc. (Copeland et al., 1995; Zessin, 1982).

We believe that the introduction of Value-Based Management of business requires the use of the economic value added model EVA.

In accordance with this model, the value of business is its book value, adjusted for the present value of future added economic values. It is important to note that a number of studies have shown the correlation between the EVA indicator and the market value of the company. By interpreting this indicator to the mathematical level, we can say that EVA is defined as operating profit after deducting taxes and expenditures from using capital. Mathematically, this can be written as follows (Favaro, 2003):

$E V A=N O P A T-W A C C * C E$,

where NOPAT - is Net Operating Profit After Taxes;

WACC - is Weighted Average Cost of Capital;

$\mathrm{CE}$ - is Capital Employed. 
The main idea of the model EVA for business is that its main shareholders are shareholders who also act as investors for the institution, should receive a certain compensation rate for the accepted risk that should be at the level of compensation for similar investment risks. If this does not happen, the owners do not benefit from the investments made in this business.

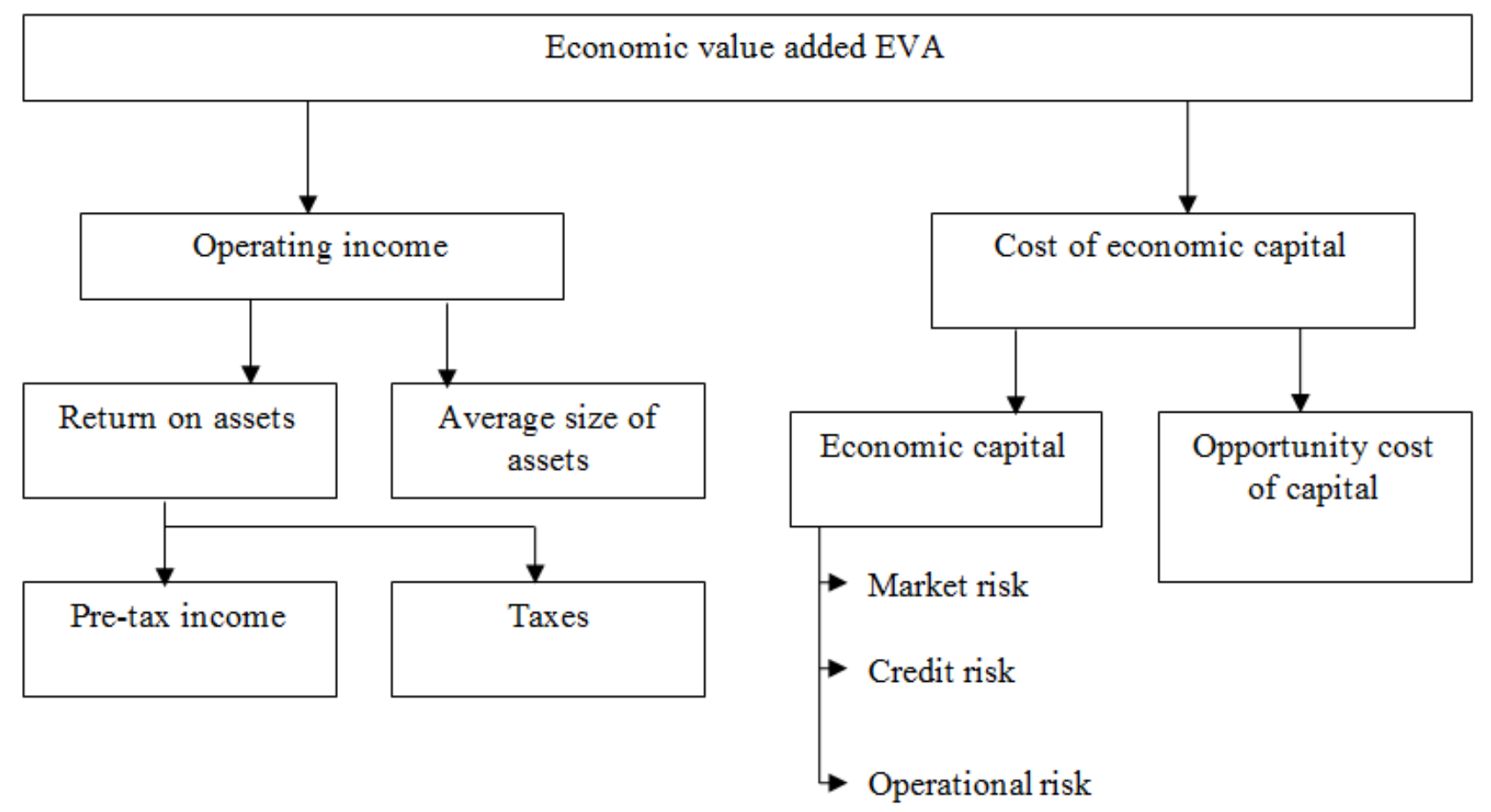

Figure 1. Model of formation of economic value added (Giammarino et al., 1989)

To sum up, it should be noted that the additional value of EVA corresponds to the efficient use of owners' capital. If this indicator is zero, then this means that the owners received the average level of compensation for the risks incurred and did not receive any additional benefits from their own investment in this business. Accordingly, the negative value of EVA indicates the low efficiency of the use of shareholders' equity and the gradual loss in value that is at their disposal.

However, it should be noted that not only material motives are present in the interest of management in the business activities. In many developed countries, such a factor as reputation, image of the manager is equally important. By achieving the highest results, the manager creates a reputation and image and thereby acquires competitive advantages in the labor market. Accordingly, the manager who has successfully worked in a managerial position is more highly valued by its owners. Having a good business reputation, such a leader can more easily find a new job in case of dismissal, will be able to choose a place that suits him as much as possible. Besides, it should be noted that trust plays an important role in the modern business. A significant number of deals are made on the basis of personal relationships, and therefore the high business reputation of management is, of course, a significant advantage for business and greatly facilitates the work of such management.

It is important to note that the specifics of the business manager's work make the latter interact with a large number of groups that are interested in business activities and take into account, to a varying degree, their interests.

By stakeholders we understand those who have an interest in business and the ability to influence it. Having investigated the interests of all interested groups, we now consider it necessary to determine the possibility of the influence of stakeholders on the company's activities. According to modern international studies, up to $80 \%$ of the value of corporate rights is not formed at the expense of their book value, but because of the intangible assets of businesses that form a corresponding reputation, trust, demonstrate its integrity and responcibility. These factors are particularly important for the formation of business value, because it is based on trust and reputation. Investigating the factors in the formation of business value, they can be divided into two groups: financial and intangible ones. Financial factors indicate the financial position of the business, its 
stability, the results of its activities, the aggregate formed cash flow. Intangible factors characterize the level of business relationships with its main stakeholders (Figure 2).

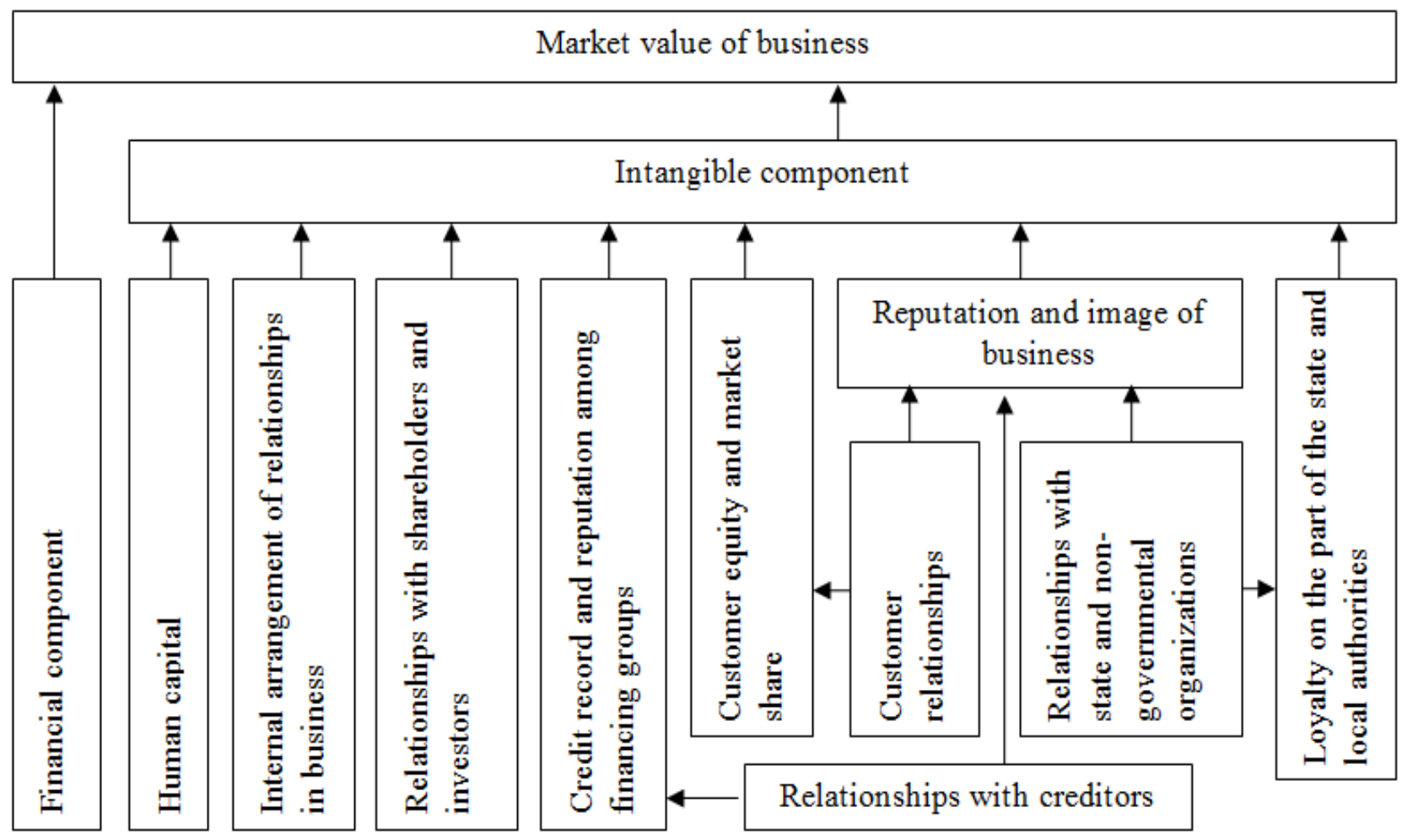

Figure 2. System of intangible drivers of market value of business (made up by the author on the basis of (Khaustova et al., 2007))

Most researchers focus on the need to manage the material factors of the formation of business value, while the influence of intangible factors on the interests of stakeholders is mainly considered through the marketing channel (reputation of business, quality of relations, brand popularity, etc. as factors of increasing the client base of the business and, accordingly, increase in profit).

Considering the current features of doing business, we believe that today the key intangible factors of valuebased management of business are:

1. Managing relationships with clients, creditors and investors, since in conditions of financial fragility it provides compensatory business opportunities and reduces the negative extraversion of crisis phenomena.

2. Increasing the level of innovation of business, which becomes especially relevant in the context of increased competition between companies, emergence of new business technologies and its virtualization, globalization of the world financial market, which makes services more affordable, common and cheap.

An important aspect of the quality of value-based management of business is to manage its quality. In our opinion, it is necessary to form the system of indicators, the control of which will allow management to take them into account when making managerial decisions, subordinating them to overall goal - maximizing the market value of business. In our opinion, in order the developed tool for improving the quality of Value-Based Management of business to be effective, it should meet the following requirements:

$>$ it should provide reliable results in the context of individual factors of the formation of business value;

$>$ this system of indicators should be based on data available for management;

$>$ the result of the use of such a system of indicators should be the decision-making aimed at increasing the value of business;

$>$ given tool should be reliable and dynamic, and therefore include the most significant drivers of the formation of business value;

$>$ the use of this tool should be effective, that is, the benefits derived from its use should not exceed the cost of creating and maintaining such a system of indicators. 
The compliance of such a tool with the given requirements in many respects depends on the set of indicators that will be included in such a system. In our opinion, the formation of such a system of indicators should take place in the context of certain components of intellectual capital as a key indicator of the quality of value-based management of business: client, organizational and human capital, and the indicators themselves should be relevant, that is, reflect the value of the intangible asset they characterize. In addition, they should be suitable for comparison.

It should be emphasized separately that before construction of the indicated tool, first of all, it is necessary to define the users for whom it should be useful. If the indicators of the formation of intellectual capital are intended for external users, then usually the volume of indicators is very limited. The problems of building such an external-oriented system are due to the fact that despite the increasing transparency of domestic business and expanding the amount of information they reveal about themselves, there are still its very tight limits.

In our opinion, the algorithm for constructing the system of indicators to evaluate various components of the quality of value-based management of business should be as follows:

1) determination of key factors for the formation of business value;

2) determination of the relationship between the components of intellectual capital and key drivers of business value increase;

3) identification of indicators in the context of each component of intellectual capital that can increase the value of business;

4) in the context of each indicator, the formation of quantitative and qualitative characteristics that allow to assess its impact on the formation of the intellectual capital of business;

5) construction of rating scales and evaluation of the rating of each indicator both for its quantitative and qualitative characteristics;

6) formation and adoption of managerial decisions based on the performed analysis;

7) assessment of the decisions made in terms of increasing the business value.

In the context of each type of business intellectual capital it is possible to isolate its drivers and those characteristics that are able to form the value of business (see in Appendix).

In the context of the driver data and the corresponding characteristics of cost formation it is necessary to classify the indicators that characterize:

$>$ effectiveness of qualitative characteristics of drivers of intellectual capital of business, which form its value;

$>$ effectiveness of quantitative characteristics of intellectual capital drivers, that form its value;

$>$ business development potential.

The relevant characteristics may have no quantitative expression.

Describing the general approach to assessing the contribution of each driver to the value of the company, it is necessary to identify those characteristics which evaluation should be used while managing and controlling the intellectual capital of business, as part of Value-Based Management of business. The first, in our opinion, should be a group of indicators that characterize the client's business capital. This group of factors include the following:

loyalty of customers as a characteristic that points to the level of customer retention, level of customer affiliation with the institution as a whole and level of relations between the customers of the company and its employees;

$>$ profitability of customers, which can characterize the quality of customer base of business and segment of the market of services in which the business operates;

$>$ availability and speed of customer feedback.

The relevant indicators are given in Table 1. 
Table 1. Indicators of estimation of the company value creation by the factors of customer equity (Khaustova et al., 2007)

\begin{tabular}{|l|l|l|l|}
\hline \multirow{2}{*}{$\begin{array}{c}\text { Factors of company } \\
\text { value creation }\end{array}$} & \multicolumn{1}{|c|}{$\begin{array}{c}\text { Effectiveness of qualitative } \\
\text { characteristics }\end{array}$} & \multicolumn{1}{|c|}{$\begin{array}{c}\text { Effectiveness of quantitative } \\
\text { characteristics }\end{array}$} & \multicolumn{1}{c|}{$\begin{array}{c}\text { Potential of company } \\
\text { development }\end{array}$} \\
\cline { 2 - 4 } Customer loyalty & $\begin{array}{l}\text { Level of customer satisfaction } \\
\text { according to the feelings of the } \\
\text { company's specialists, presence } \\
\text { of personal relationships between } \\
\text { the company's specialists and its } \\
\text { customers }\end{array}$ & $\begin{array}{l}\text { The share of clients who use the } \\
\text { services of this company only }\end{array}$ & $\begin{array}{l}\text { The presence and share of } \\
\text { customers ready to recommend } \\
\text { the company to their partners, } \\
\text { opportunities to expand their own } \\
\text { market share }\end{array}$ \\
\hline $\begin{array}{l}\text { Profitability of } \\
\text { customers }\end{array}$ & $-\quad \begin{array}{l}\text { The level of expenses for } \\
\text { attracting a new customer in the } \\
\text { total additional profit of the } \\
\text { company, the efficiency of } \\
\text { marketing expenses }\end{array}$ & $\begin{array}{l}\text { Availability of opportunities for } \\
\text { obtaining additional benefits } \\
\text { from existing customers by } \\
\text { expanding the range of company } \\
\text { services }\end{array}$ \\
\hline Customer feedback & $\begin{array}{l}\text { Practicality and validity of the } \\
\text { main offers of the customers }\end{array}$ & $\begin{array}{l}\text { The proportion of successfully } \\
\text { implemented customer offers in } \\
\text { their total number }\end{array}$ & $\begin{array}{l}\text { Possibilities for development of } \\
\text { the system of interaction with the } \\
\text { customer in order to more fully } \\
\text { meet his needs }\end{array}$ \\
\hline
\end{tabular}

Determination of the indicators given in the Table 1, in our opinion, will enable business management to assess the customer's capital of the institution and create the basis for managing this type of capital within the framework of value-based management. The formulas for determining the effectiveness of quantitative characteristics are given below.

$C_{l}=\frac{C L_{u}}{C L_{t}}$

where $C_{l}$ - share of customers, who use the services of only this company;

$C L_{u}$ - number of customers who do not use the services of another company;

$C L_{t}-$ total number of customers of the company.

$R E_{c}=\frac{E_{c}}{\Delta P}$,

where $R E_{c}-$ cost of attracting a new client in the company's total additional profits;

$E_{c}$ - average costs of attracting a new client;

$\Delta P$ - increase in company profits.

$M E=\frac{M}{(N I R+N C R+T R)}$,

where $M E$ - efficiency of marketing costs;

$M$ - company costs for marketing in the current year;

$N I R$ - net interest income received by the company in the current period;

$N C R$ - net commission income received by the company in the current period;

$T R$ - trade income received by the company in the current period.

$R I_{c}=\frac{I_{c}}{P_{c}}$,

where $R E_{c}$ - proportion of successfully implemented customer offers in their total number; 
$I_{c}$ - successfully implemented customer offers;

$\Delta P$ - total number of customer offers of the company.

The next component of the intellectual capital of the company, the management of which may form its added value, is social capital, which, in the first place, is built on the basis of:

$>$ competitiveness of the company, its image, quality of its services;

$>$ reliability of the partners of the company whom it cooperates with and whom the quality of services provided to customers depends on;

relations with the main stakeholders, who characterize the company's activity in society, form opinions about it in society and in related economic spheres (Table 2).

Table 2. Indicators of estimation of the company value creation by the factors of social capital

\begin{tabular}{|l|l|l|l|}
\hline \multirow{2}{*}{$\begin{array}{c}\text { Factors of company } \\
\text { value creation }\end{array}$} & $\begin{array}{c}\text { Efficiency of qualitative charac- } \\
\text { teristics }\end{array}$ & $\begin{array}{c}\text { Efficiency of quantitative char- } \\
\text { acteristics }\end{array}$ & $\begin{array}{c}\text { Potential of company develop- } \\
\text { ment }\end{array}$ \\
\hline Competitiveness & $\begin{array}{l}\text { Distribution of the company's } \\
\text { brand, the main qualitative } \\
\text { advantages of the company's } \\
\text { products compared with the } \\
\text { main competitors }\end{array}$ & $\begin{array}{l}\text { The market share of the compa- } \\
\text { ny in each segment of the market } \\
\text { of services, the dynamics of the } \\
\text { market share of the company in } \\
\text { relation to the main competitors }\end{array}$ & $\begin{array}{l}\text { The main quality deficiencies of } \\
\text { the company's products com- } \\
\text { pared with the main competitors }\end{array}$ \\
\hline $\begin{array}{l}\text { Reliability of the part- } \\
\text { ners }\end{array}$ & $\begin{array}{l}\text { Reputation of the company and } \\
\text { other partners of the company, } \\
\text { their responsibility for failure to } \\
\text { fulfill their obligations to the } \\
\text { company }\end{array}$ & $\begin{array}{l}\text { The level of economic disbene- } \\
\text { fit as a result of failure of the } \\
\text { company's partners to fulfill } \\
\text { their obligations }\end{array}$ & $\begin{array}{l}\text { Availability of cooperation with } \\
\text { alternative partners }\end{array}$ \\
\hline $\begin{array}{l}\text { Establishment of rela- } \\
\text { tions with stakeholders }\end{array}$ & $\begin{array}{l}\text { The level of relations between } \\
\text { representatives of the main } \\
\text { stakeholders with the company, } \\
\text { development of corporate and } \\
\text { social responsibility }\end{array}$ & - & $\begin{array}{l}\text { Prospects for the company to } \\
\text { enter a prestigious group, asso- } \\
\text { ciation, union, etc. }\end{array}$ \\
\hline
\end{tabular}

Use of the indicators shown in the Table 2, in our opinion, will create the basis for the company to manage its intellectual capital associated with the connections that the firm has on financial markets, and relationships with companies that can affect the value of business. Formulas for determining the effectiveness of quantitative characteristics are given below (Damodaran, 2009).

$M S H_{b}=\frac{R_{p}}{R S_{p}}$,

where $\mathrm{MSH}_{b}$ - company's share in the service market segment;

$R_{c}$ - turnover of the company in the service market segment;

$R S_{p}$ - system turnover of the company in the service market segment.

$I_{m}=\frac{\Delta M S H_{b}}{\Delta M S H_{s}}$,

where $I_{m}$-dynamics of the market share of the company in relation to the main competitors;

$\mathrm{MSH}_{s}$ - market share of the competitor in the service market segment.

The next component of intellectual capital is its innovative capital. In our opinion, it should be evaluated by the effectiveness of the relevant innovation activity of the company and its specialists and by the effectiveness of innovative products implemented in the company activity (Table 3 ).

Study of the indicators shown in Table 3 within the framework of value-based management enables to manage the competitive prospects of the company and creates the basis for obtaining leading positions in the market of services. 
Table 3. Indicators of estimation of the company value creation by the factors of innovation capital

\begin{tabular}{|l|l|l|l|}
\hline \multirow{2}{*}{$\begin{array}{c}\text { Factors of company } \\
\text { value creation }\end{array}$} & $\begin{array}{c}\text { Efficiency of qualitative charac- } \\
\text { teristics }\end{array}$ & $\begin{array}{c}\text { Efficiency of quantitative char- } \\
\text { acteristics }\end{array}$ & $\begin{array}{c}\text { Potential of company develop- } \\
\text { ment }\end{array}$ \\
\hline $\begin{array}{l}\text { Innovative activity of } \\
\text { the company }\end{array}$ & $\begin{array}{l}\text { Level of development of inno- } \\
\text { vative processes in the company }\end{array}$ & $\begin{array}{l}\text { The share of costs for the devel- } \\
\text { opment of innovations in net } \\
\text { interest and commission income }\end{array}$ & $\begin{array}{l}\text { Availability of the material base } \\
\text { and specialists for the develop- } \\
\text { ment of the company's innova- } \\
\text { tive processes }\end{array}$ \\
\hline $\begin{array}{l}\text { Innovative products of } \\
\text { the company }\end{array}$ & $\begin{array}{l}\text { The success of the implementa- } \\
\text { tion of innovative ideas (prod- } \\
\text { ucts) into the company's activity }\end{array}$ & $\begin{array}{l}\text { The share of company profit } \\
\text { formed by innovative products } \\
\text { (ideas) in the company's total } \\
\text { profit }\end{array}$ & $\begin{array}{l}\text { Possibilities of successful im- } \\
\text { plementation of all innovative } \\
\text { ideas developed by the special- } \\
\text { ists of the company }\end{array}$ \\
\hline
\end{tabular}

The formulas for determining the effectiveness of quantitative characteristics are given below.

$$
R I E=\frac{I E}{(N I R+N C R)},
$$

where $R I E$ - share of costs for the development of innovations in net interest and commission income; $I E$ - company costs for the development of innovations.

$$
R I P=\frac{R I n}{P},
$$

(9)

where RIP - share of company profit formed by innovative products (ideas) in the company's total profit; $R I n$ - company profit formed by innovative products (ideas);

$R$ - company's total profit.

An important component of intellectual capital for the purpose of managing business value is its process capital, which makes it possible to understand the internal organization of business as an organization, since the business is not a set of financial resources, but organized activity to provide services based on appropriate permissions.

The following factors play an important role in the organization of business activity (Brooks et al., 2004):

$>$ establishment of information channels within the organization, that is, its ability to collect the necessary information in a timely manner and transfer this knowledge among specialists;

$>$ establishment of business processes, interaction of structural units, uniqueness of instructions to be followed by the employee of the company, and specific determination of the algorithm of his actions in any working situation;

$>$ level of technologies used by business, their relevance (Table 4).

Table 4. Indicators of estimation of the company value creation by the factors of process capital

\begin{tabular}{|c|c|c|c|}
\hline $\begin{array}{c}\text { Factors of company } \\
\text { value creation }\end{array}$ & $\begin{array}{c}\text { Efficiency of qualitative charac- } \\
\text { teristics }\end{array}$ & $\begin{array}{c}\text { Efficiency of quantitative char- } \\
\text { acteristics }\end{array}$ & $\begin{array}{c}\text { Potential of company develop- } \\
\text { ment }\end{array}$ \\
\hline $\begin{array}{c}\text { Establishment of in- } \\
\text { formation channels }\end{array}$ & $\begin{array}{c}\text { Speed and efficiency of business } \\
\text { communications, their regula- } \\
\text { tion by internal instructions }\end{array}$ & $\begin{array}{c}\text { The company share of costs for } \\
\text { IT in total company costs }\end{array}$ & $\begin{array}{c}\text { Possibilities of introduction of } \\
\text { the latest information technolo- } \\
\text { gies }\end{array}$ \\
\hline $\begin{array}{c}\text { Establishment of busi- } \\
\text { ness processes }\end{array}$ & $\begin{array}{c}\text { Regulation of business process- } \\
\text { es, their flexibility and speed of } \\
\text { delivering products of the com- } \\
\text { pany }\end{array}$ & $\begin{array}{c}\text { The share of administrative } \\
\text { costs of the company in the } \\
\text { company's net income }\end{array}$ & $\begin{array}{c}\text { The presence of duplication of } \\
\text { functions and tasks }\end{array}$ \\
\hline $\begin{array}{c}\text { Development of tech- } \\
\text { nologies in the compa- } \\
\text { ny }\end{array}$ & $\begin{array}{c}\text { Implementation of modern } \\
\text { technologies in the company }\end{array}$ & $\begin{array}{c}\text { Perspective technologies that } \\
\text { can be implemented in the } \\
\text { company }\end{array}$ \\
\hline
\end{tabular}

Use of indicators presented in Table 4 in the value-based management creates the basis for the accumulation of business value through the improvement of its internal organization. The formulas for determining the effectiveness of quantitative characteristics are given below. 
$R F=\frac{F}{(N I R+N C R)}$,

where $R F$ - share of business costs for information technologies in net income of the company;

$F$ - company costs for information technologies.

$A E E=\frac{A E}{(N I R+N C R+T R)}$,

where $A E E$ - share of administrative costs in the company's net income;

$A E$ - general administrative costs of the company in the current period;

$N I R$ - net interest income received by the company in the current period;

$N C R$ - net commission income received by the company in the current period;

$T R$ - trade income received by the company in the current period.

The last but not less important factor in the formation of intellectual capital of the company is its human capital. While managinig it, in our opinion, it is worth paying attention to such indicators as:

education of the company's specialists as the basis of their professional activities and one of the components of the overall knowledge of any organization, and thus serves as the basis for the current results of the business and its future prospects;

level of their experience as a characteristic that indicates the ability to apply knowledge by the company's specialists in practice;

efficiency of human resources of the company as the main indicator of the efficiency of their use;

$>$ employee loyalty to the company (Table 5).

Table 5. Indicators of estimation of the company value creation by the factors of human capital

\begin{tabular}{|c|c|c|c|}
\hline \multirow{2}{*}{$\begin{array}{c}\text { Factors of company } \\
\text { value creation }\end{array}$} & Efficiency of qualitative characteristics & $\begin{array}{c}\text { Efficiency of quantitative char- } \\
\text { acteristics }\end{array}$ & $\begin{array}{c}\text { Potential of company } \\
\text { development }\end{array}$ \\
\cline { 2 - 4 } Education & $\begin{array}{c}\text { Sufficiency of the educational level of } \\
\text { specialists for their positions, awareness } \\
\text { of the latest trends in the company }\end{array}$ & $\begin{array}{c}\text { Fate of business professionals } \\
\text { without higher education with } \\
\text { the necessary specialization }\end{array}$ & $\begin{array}{c}\text { Implementation of } \\
\text { additional trainings by } \\
\text { the company for its } \\
\text { own specialists }\end{array}$ \\
\hline Experience & $\begin{array}{c}\text { Availability of knowledge about the com- } \\
\text { pany as a whole and a specific branch, } \\
\text { presence of experience in other companies } \\
\text { and economic entities }\end{array}$ & $\begin{array}{c}\text { Average length of work in the } \\
\text { company of specialists of differ- } \\
\text { ent sectors and levels }\end{array}$ & $\begin{array}{c}\text { Presence of young } \\
\text { professionals with } \\
\text { potential for career } \\
\text { growth }\end{array}$ \\
\hline Effectiveness & $\begin{array}{c}\text { New ideas offered by the company's } \\
\text { specialists }\end{array}$ & $\begin{array}{c}\text { Share of net income per em- } \\
\text { ployee }\end{array}$ & - \\
\hline Loyalty of employees & $\begin{array}{c}\text { Quality of the relations between the em- } \\
\text { ployees, working atmosphere, loyalty of } \\
\text { the company's specialists to the institu- } \\
\text { tion, their perception of key management } \\
\text { decisions and overall strategy of the com- } \\
\text { pany }\end{array}$ & Level of personnel turnover & $\begin{array}{c}\text { Organization of } \\
\text { events "team- } \\
\text { building" }\end{array}$ \\
\hline
\end{tabular}

The group of indicators presented in the Table 5 is an important part of the activity of any company, especially in the services sector, and therefore human capital management based on the selected indicators is a significant component of value-based management.

Therefore, in our opinion, the allocation of channels of influence of intangible factors of formation of the value of business on the quality of value-based management, which is expressed through the growth of intellectual capital of business, will enable to optimize managerial costs and improve the quality of value-based management of business. On the basis of the selected indicators, it makes sense to periodically determine the rating of the efficiency of using the company's intellectual capital, but for a more detailed understanding of the strengths and weaknesses of the intellectual capital of business and effective management of it, it is necessary, based on the proposed indicators, to analyze the intellectual capital of business. 


\section{Conclusions}

In order to study the relationship between value-based management of business and stakeholders, the authors have ranked the guarantors of business in the direction of its impact on the level of satisfaction of their interests:

stakeholders of direct influence (influence of value-based management on their welfare level is direct: due to rising wages, dividend payments, share prices, etc.);

$>$ stakeholders of indirect influence (influence of value-based management on their welfare level is indirect: due to the increase in the level of reliability that ensures the fulfillment of their obligations);

$>$ stakeholders of systemic influence (effective value-based management in separate companies increases the overall level of system stability, public confidence in firms and the effectiveness of economic interaction between enterprises and other entities of the economy).

Consequently, the study of intangible factors of growth of the company value enables to identify gaps in the practice of company management. At the same time, conditions for the development of economic thinking of managers and employees of the company based on the analysis of key factors of value are provided.

\section{References}

1. Beck, K. (1999). Extreme Programming Explained: Embrace Change, Addison-Wesley.

2. Brooks, R., Gray, J. B. (2004). History of the forecasters. Journal of Portfolio Management, 31, 113-123.

3. Copeland, Tom, Koller, Tim, Murrin, Jack (1995). Valuation. Measuring and Managing the Value of Companies. 2nd ed. McKinsey \& Company, Inc. Published by John Wiley \& Sons, Inc., 128 p.

4. Damodaran, Aswath (2009). Valuing Companies with intangible assets. Retrieved from http://people.stern.nyu.edu/adamodar/pdfiles/papers/intangibles.pdf.

5. Edvinsson, L., Malone, M.S. (1997). Intellectual Capital. Realizing Your Company's True Value by Finding Its Hidden Brainpower. New York, Harper Business, p. 5.

6. Favaro, John (2003). Value-Based Management and Agile Methods. In Proceedings of 4th International Conference on XP and Agile Methods.

7. Giammarino, R., Schwortz, E, Zecher, J. (1989). Market valuation of bank assets and deposit insurance in Canada. Canadian Journal of Economics, XXII(1), 109-127.

8. Khaustova, V. Ye., Kurochkina, I. H., Dulenko, A. L. (2007). Teoretychni zasady otsinky vartosti biznesu korporatyvnykh struktur i rozpiznavannya yikh za rivnem kapitalizatsiyi [Theoretical principles of estimating the value of business of corporate structures and their recognition by level of capitalization]. In Corporations and integrated structures: problems of science and practice: Monograph. Kharkiv.: VD "INZHEK", pp. 326-342.

9. Kroeker, Curtis, (2013). How To Boost Your Company's Value: Mind the Intangible Assets. Retrieved from https://www.inc.com/curtis-kroeker/intangible-assets.html.

10. Millar, Allan (2013). How To Calculate Intangible Assets In Company Valuation. Retrieved from https://www.seeitmarket.com/calculate-intangible-assets-company-valuation-13632/.

11. Modigliani, F., Miller, M. (1958). The cost of capital, corporation finance, and the theory of investment. American Economic Review, pp. 261-297.

12. Rea, Nick, and Davis, Adrian (2009). Intangible assets: what are they worth and how should that value be communicated? PricewaterhouseCoopers, London.

13. Three approaches to valuing intangible assets (2012). Third Edition, by American Institute of Certified Public Accountants, Inc.

14. Timmerman, Jessica (2015). Valuing Intangible Assets. Quantive Business Valuations. Retrieved from http://www.axial.net/forum/valuing-intangible-assets/.

15. Tobin, J. (1996). An Essays in Economics. Vol. 1: Macroeconomics. Amsterdam - London. Introduction. P. XIII, $411 \mathrm{p}$.

16. Understanding Intangible Assets and Real Estate: A Guide for Real Property Valuation Professionals (2016). By IAAO Special Committee on Intangibles.

17. Zessin, A. (1982). Unternehmensbewertung von Kreditinstituten, Gottinger Hefte zur Bankbetriebslehre und Unternehmensfinanzierung. Verlag Otto Schwarz, Gottingen, Germany, 435 p. 


\section{Appendix}

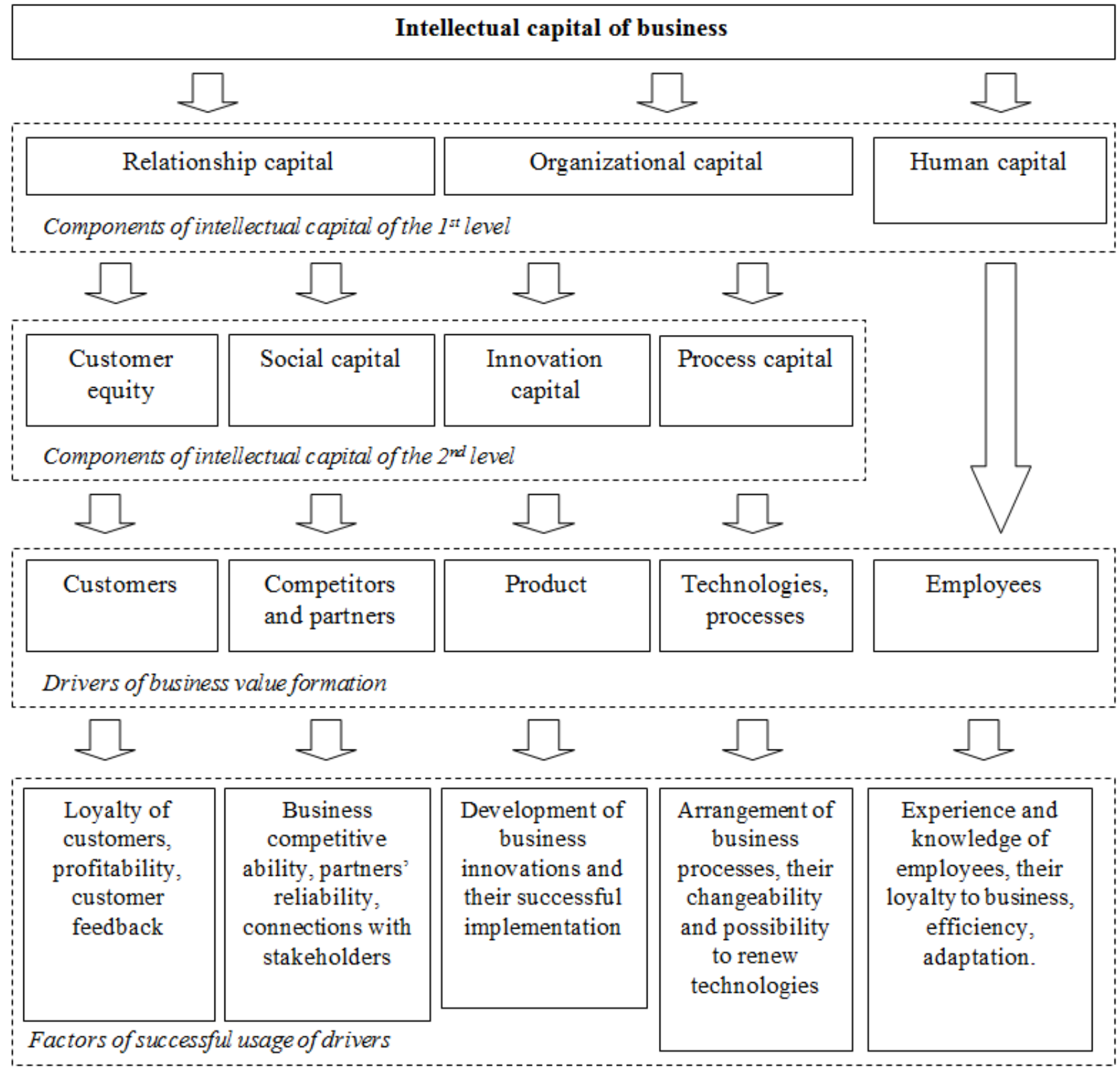

Figure 3. Drivers of formation of business value by increasing its intellectual capital (Giammarino et al., 1989) 